\title{
Expression of Axl and its prognostic significance in human breast cancer
}

\author{
GAOYUAN JIN ${ }^{1}$, ZHENZHEN WANG $^{2}$, JIANGUANG WANG $^{1}$, LIKE ZHANG ${ }^{1}$, \\ YANBIN CHEN $^{1}$, PENGFEI YUAN ${ }^{1}$ and DECHUN LIU ${ }^{1}$ \\ Departments of ${ }^{1}$ Breast Surgery and ${ }^{2}$ Oncology, The First Affiliated Hospital, \\ College of Clinical Medicine of Henan University of Science and Technology, Luoyang, Henan 471003, P.R. China
}

Received January 27, 2016; Accepted October 27, 2016

DOI: $10.3892 / \mathrm{ol} .2016 .5524$

\begin{abstract}
Breast cancer is the most common malignant cancer and second leading cause of cancer-related death among women, and its prevalence continues to increase. Axl overexpression has been identified in the many types of human cancer, and it has been demonstrated to participate in signaling pathways related to carcinogenesis and cancer development. In the present study, Axl expression was examined by performing immunohistochemical staining in 60 breast cancer tumors and 40 benign breast lesions ( 25 mammary dysplasia and 15 breast fibroadenoma). In total, $34(56.67 \%)$ cancer tissues and $13(32.5 \%)$ benign breast lesions were classified as exhibiting high levels of Axl expression, indicating a significant association between malignancy and high Axl expression. High Axl expression was also associated with estrogen receptor (ER) positivity $(\mathrm{P}=0.028)$, progesterone receptor $(\mathrm{PR})$ positivity $(\mathrm{P}=0.007)$, and poor tumor differentiation $(\mathrm{P}=0.033)$. No significant associations were observed between Axl expression and age, tumor size, lymph node metastasis, tumor node metastasis staging, human epidermal growth factor receptor 2 and Ki67 antigen. The Kaplan-Meier survival analysis and Cox proportional hazard model both demonstrated that there was no statistical difference between Axl expression and breast cancer prognosis. However, it remains unclear whether the expression of Axl is correlated with the prognosis of luminal type breast cancer patients.
\end{abstract}

\section{Introduction}

Breast cancer is one of the most common malignant cancers among women, and in some cases, is life threatening (1). The

Correspondence to: Dr Dechun Liu, Department of Breast Surgery, The First Affiliated Hospital, College of Clinical Medicine of Henan University of Science and Technology, 24 Jinghua Road, Luoyang, Henan 471003, P.R. China

E-mail: liudechun2008@126.com

Key words: Axl, breast cancer, clinicopathological features, patient prognosis
American Cancer Society has reported that new cases of invasive breast cancer in the USA will reach 246,660 by 2016 , accounting for $29 \%$ of de novo malignancies among women, and breast cancer-related mortality is estimated to reach 40,450 in 2016 (2). In China, breast cancer is the most prevalent cancer in women, and the number of new cases diagnosed is increasing every year (3). Developing novel biomarkers of breast cancer may improve knowledge of how breast cancer develops, and potentially allow more efficient therapeutic strategies to be implemented.

Tyrosine-protein kinase receptor UFO (Axl), belongs to the TAM family of receptor tyrosine kinases, which consists of Axl, tyrosine-protein kinase receptor Tyro3, and tyrosin protein kinase Mer. Axl is a transforming gene that was originally isolated from patients with chronic myelogenous leukemia (4). The growth arrest specific gene 6 (Gas6) is a ligand of Axl, and the binding of Gas6 to Axl results in the dimerization of Gas6/Axl complexes, activating intracellular tyrosine kinase, and triggering a series of signal transduction and biological effects (5). It has previously been reported that Axl participates in signaling pathways related to carcinogenesis and cancer development, such as the phosphatidylinositol 3-kinase/protein kinase B pathway, the Janus kinase/signal transducers and activators of transcription pathway, and nuclear factor- $\kappa \mathrm{B}$ signaling pathway (6-8). It has also been demonstrated that Axl is an underlying oncogenic factor involved in the epithelial-mesenchymal transition, which allows epithelial cells to undergo cell migration and invasion, and thus contribute to tumor metastasis (9). Axl has been implicated in different types of human cancer and is related to their development and clinical prognosis. These include: Gastric (10), lung (11), bladder (12), thyroid (13), pancreatic (14) and colon (15) cancer.

Methods of blocking Axl expression by RNA silencing or Axl inhibition have been studied in vivo and in vitro. The results of these studies suggest that Axl is a promising target in cancer therapy. For example, LY2801653, a multi kinase inhibitor of the hepatocyte growth factor receptor (MET) and Axl, is capable of inhibiting cell migration, proliferation and anti-tumor activities (16). The effects of inhibiting Axl expression by Amuvatinib (MP470) have been studied in gastrointestinal stromal tumors and breast cancer (17). Furthermore, Foretinib, an experimental multi kinase inhibitor 
targeting MET, vascular endothelial growth factor receptor 2, and Axl, may inhibit the proliferation and survival of colorectal cancer cells (18).

The association between Axl and breast cancer has been widely researched. However, the clinicopathological significance and the prognostic role of Axl in breast cancer remains controversial, and there have been few studies investigating the exact role of Axl in breast cancer. The present study aimed to measure Axl expression in breast cancer tissue and noncancerous lesions by immunohistochemical staining, and to explore the prognostic value of Axl in patients with breast cancer.

\section{Materials and methods}

Patients and surgical specimens. Specimens were obtained from 60 female patients (average age, 50.60土1.36) undergoing surgery at the Department of Breast Surgery, the First Affiliated Hospital, Henan University of Science and Technology, between January and August 2010. Informed consent was obtained from all the patients to use the surgical specimens for scientific research. The specimens included 60 cases of breast infiltrative ductal cancer tissues and 40 cases of benign breast lesions (25 mammary dysplasia and 15 breast fibroadenoma). The median age of patients at breast cancer diagnosis was 48 years old (range, 28-80 years). None of the patients received chemoradiotherapy or endocrine therapy before surgery, and there were no obvious abnormalities in the preoperative function of the heart, lungs, liver, or kidney of any patients. There was also no distant metastasis detected in any patients before operations were performed. The clinicopathological characteristics of the patients with breast cancer are presented in Table I.

Postoperative treatment was performed according to the National Comprehensive Cancer Network (NCCN) guidelines. The tissue specimens were fixed in $10 \%$ formaldehyde solution and embedded in paraffin blocks. Paraffin blocks were cut into sections $3 \mu \mathrm{m}$ thick. All cases of breast cancer were confirmed by professional pathologists by hematoxylin-eosin (HE) staining, and were categorized according to the 7th edition of the American Joint Committee on Cancer Tumor-Node-Metastasis (TNM) stage classification (19). The molecular subtyping of breast cancer followed the guidelines issued at the St. Gallen International Breast Cancer Conference 2013 (20); the luminal type included luminal A and luminal B type breast cancer, the non-luminal type included Erb-B2 overexpression and basal-like type breast cancer.

ImmunohistochemistryIHC. The paraffin sections of cancerous and benign lesions were baked for $2 \mathrm{~h}$ at $60^{\circ} \mathrm{C}$, deparaffinized with dimethylbenzene and hydrated in gradient ethanol. Tissue antigen retrieval was performed using citrate sodium buffer ( $\mathrm{pH}$ 6.0) at $95^{\circ} \mathrm{C}$ for $15 \mathrm{~min}$ and cooled at room temperature for 30 min. Endogenous peroxidase was blocked with methanol containing $3 \% \mathrm{H}_{2} \mathrm{O}_{2}$ for $10 \mathrm{~min}$, then the slides were treated with 5\% normal goat serum (SL2; Beijing Solarbio Science \& Technology Co., Ltd., Beijing, China) for $30 \mathrm{~min}$ to limit non-specific binding. The anti-Axl rabbit polyclonal antibody (1:100; ab37861; Abcam, Cambridge, MA, USA) was overlaid on the sections and incubated overnight at $4^{\circ} \mathrm{C}$. Following re-warming at room temperature for $1 \mathrm{~h}$ and three washes in PBS (AR0030; Wuhan Boster Biological Technology, Ltd., Wuhan, China), sections were incubated with horseradish peroxidase-labeled secondary antibody (1:500; SA00001-2; Wuhan Sanying Biotechnology, Wuhan, China) for $30 \mathrm{~min}$ at room temperature. Diaminobenzidine (DAB-0031; Fuzhou Maixin Biotech Co., Fuzhou, China) was used for antigen detection. Subsequently, the slides were counterstained with hematoxylin for $10 \mathrm{sec}$, dehydrated in gradient ethanol and mounted, and then viewed under an optical microscope. Negative controls used for comparison were incubated with phosphate buffer saline instead of the primary antibody.

Evaluation of immunohistochemical staining. Sections were evaluated independently by two different investigators with no prior knowledge of patient clinical information, and disagreements were resolved through discussion. Human epidermal growth factor receptor 2 (HER-2) staining was carried out and evaluated according to the standards provided by NCCN: -, ,\pm+ were all defined as negative; +++ as positive, and FISH quantitative determination was conducted when the staining score $\geq++(21)$.

Axl expression score was based on an intensity score (IS) and a proportion score (PS). IS was graded on the following scale: No staining, 0; mild staining, 1; moderate staining, 2; intense staining, 3; extremely intense staining, 4 . The PS was graded as follows: $\leq 10 \%, 0 ; 11-25 \%, 1 ; 26-50 \%, 2 ; 51-75 \%$, $3 ;>75 \%, 4$. Therefore, the range of the combined staining score (IS+PS) was $0-8$. A total score $\leq 1$ was considered to be negative (-); a score of 2-3 was considered to be weakly positive (+); a score of 4-6 was considered to be positive (++); a score of 7-8 was considered to be strong positive (+++). Scores of (-) and (+) were regarded as low levels of expression, whereas scores of $(++)$ and $(+++)$ were regarded as high levels of expression.

Follow-up information. The 60 breast cancer patients were followed up by telephone conversation, although home visits were also undertaken if required. Telephone numbers and addresses were acquired from patient records. The follow-up deadline was September 2015. Patient survival time was calculated from the date of operation until the date of cancer-related mortality. Disease-free survival time (DFS) and overall survival time (OS) were adopted as prognostic indexes. The DFS events included locoregional recurrence, distant metastasis and contralateral breast cancer. OS events included all cancer-related mortality. Recurrence, distant metastasis and contralateral metastasis of patients were confirmed by X-ray plain film, ultrasonography, computed tomography and pathological examination.

Statistical analysis. The association between Axl expression and clinicopathological features were analyzed by $\chi^{2}$ or Fisher's exact tests. Correlational analyses were conducted using the analysis of Spearman rank correlation. Patient survival was estimated using the Kaplan-Meier method and compared with the log rank test. Prognostic factors were analysed by the Cox proportional hazard model, and the assignment of risk factors is presented in Table II. All statistical analyses were performed using the SPSS 21.0 program (IBM SPSS, Inc., Armonk, NY, 
Table I. Patient clinicopathological characteristics.

\begin{tabular}{|c|c|}
\hline \multicolumn{2}{|c|}{ Patient characteristics, $n=60$} \\
\hline Variable & Number $(\%)$ \\
\hline \multicolumn{2}{|l|}{ Age, years } \\
\hline$\leq 50$ & $33(55.0)$ \\
\hline$>50$ & $27(45.0)$ \\
\hline \multicolumn{2}{|l|}{ Histological grade } \\
\hline $\mathrm{G} 1$ & $13(21.7)$ \\
\hline $\mathrm{G} 2 / \mathrm{G} 3$ & $47(78.3)$ \\
\hline \multicolumn{2}{|l|}{ Tumor size, $\mathrm{cm}$} \\
\hline$<2$ & $24(40.0)$ \\
\hline$\geq 2$ & $36(60.0)$ \\
\hline \multicolumn{2}{|l|}{ Lymph node status } \\
\hline No & $35(58.3)$ \\
\hline $\mathrm{N}+$ & $25(41.7)$ \\
\hline \multicolumn{2}{|l|}{ TNM stage } \\
\hline $\mathrm{I}$ & $19(31.7)$ \\
\hline II & $28(46.7)$ \\
\hline III & $13(21.7)$ \\
\hline \multicolumn{2}{|l|}{ ER } \\
\hline Negative & $25(41.7)$ \\
\hline Positive & $35(58.3)$ \\
\hline \multicolumn{2}{|l|}{ PR } \\
\hline Negative & $32(53.3)$ \\
\hline Positive & $28(46.7)$ \\
\hline \multicolumn{2}{|l|}{ HER-2 } \\
\hline Negative & $41(68.3)$ \\
\hline Positive & $19(31.7)$ \\
\hline \multicolumn{2}{|l|}{$\mathrm{Ki}-67, \%$} \\
\hline$\leq 14$ & $19(31.7)$ \\
\hline$>14$ & $41(68.3)$ \\
\hline \multicolumn{2}{|l|}{ Molecular subtype } \\
\hline Luminal type & $36(60.0)$ \\
\hline Non-luminal type & $24(40.0)$ \\
\hline
\end{tabular}

TNM, Tumor-Node-Metastasis; ER, estrogen receptor; PR, progesterone receptor; HER-2, human epidermal growth factor receptor 2; Ki-67, antigen Ki-67.

USA). $\mathrm{P}<0.05$ was considered to indicate a statistically significant difference.

\section{Results}

Axl is highly expressed in malignant breast cancer tissue compared with benign breast lesions. Positive immunoreactivity for Axl was mainly observed in the cell cytoplasm and membrane; the positive cells were stained brown and diffusely distributed (Fig. 1). In total, $34(56.67 \%)$ patients with breast cancer were classified as ++ or +++ , indicating high levels of Axl expression. Regarding Axl immunoreactive intensity,
Table II. Classification and assignment of prognostic influence factors in patients.

\begin{tabular}{|c|c|}
\hline Variables & $\begin{array}{l}\text { Variable classification } \\
\text { and assignment }\end{array}$ \\
\hline Age, years & $\leq 50=0,>50=1$ \\
\hline Histological grade & $\mathrm{G} 1=0, \mathrm{G} 2 / \mathrm{G} 3=1$ \\
\hline Tumor size & $<2 \mathrm{~cm}=1, \geq 2 \mathrm{~cm}=0$ \\
\hline Lymph node status & $\mathrm{N} 0=0, \mathrm{~N}+=1$ \\
\hline TNM stage & $\mathrm{I}=0, \mathrm{II} / \mathrm{III}=0$ \\
\hline ER & Negative $=0$, positive $=1$ \\
\hline PR & Negative $=0$, positive $=1$ \\
\hline HER-2 & Negative $=0$, positive $=1$ \\
\hline $\mathrm{Ki}-67$ & $\leq 14 \%=0,>4 \%=1$ \\
\hline Molecular subtype & $\begin{array}{l}\text { Non-luminal type }=0 \text {, } \\
\text { luminal type }=1\end{array}$ \\
\hline Axl & Negative $=0$, positive $=1$ \\
\hline DFS & Month(s) \\
\hline DFS status & $\begin{array}{l}\text { Metastasis or recurrence }=0, \\
\text { truncated }=1\end{array}$ \\
\hline OS & Month(s) \\
\hline OS status & Death $=0$, truncated $=1$ \\
\hline
\end{tabular}

TNM, Tumor-Node-Metastasis; ER, estrogen receptor; PR, progesterone receptor; HER-2, human epidermal growth factor receptor 2; Ki-67, antigen Ki-67; Axl, tyrosine-protein kinase receptor UFO; DFS, disease-free survival time; OS, overall survival time.

16 patients were classified as negative, 10 as weak, 18 as moderate and 16 as intense. Furthermore, there were 13 patients with benign breast lesions exhibiting high expression of Axl, which accounted for $32.50 \%$ of all benign breast lesion cases (13/40). There was a significant difference in Axl expression between malignant breast cancer and benign breast lesions $(\mathrm{P}=0.018$; Table III $)$.

Correlation between Axl expression and clinicopathological characteristics. There was no significant correlation between Axl expression and age, tumor size, lymph node metastasis, TNM staging, HER-2, and the expression of Ki67 protein, which is associated with cell proliferation. However, a significant correlation was observed between Axl expression and tumor histologic grade, estrogen receptor (ER) expression and progesterone receptor $(\mathrm{PR})$ expression $(\mathrm{P}=0.033$, $\mathrm{P}=0.028, \mathrm{P}=0.007$; Table IV). Increased expression of $\mathrm{Axl}$ in luminal breast cancer was observed in $69.44 \%(25 / 36)$ of cases, and was significantly higher than positive Axl expression in non-luminal breast cancer which was $37.50 \%(9 / 24)$, $(\mathrm{P}=0.014$; Table IV) Moreover, Spearman rank correlation demonstrated that Axl expression was positively correlated with histologic grade $(\mathrm{r}=0.275, \mathrm{P}=0.034), \mathrm{ER}(\mathrm{r}=0.284$, $\mathrm{P}=0.028)$ and $\mathrm{PR}(\mathrm{r}=0.364, \mathrm{P}=0.007$; all Table V).

Correlation between Axl expression and prognosis of patients with breast cancer. In the present study, 5 patients were lost to follow-up after surgery. In total, 12 cases of 
Table III. Difference of Axl expression between malignant breast cancer and benign breast lesions.

\begin{tabular}{lccr}
\hline Axl expression & Breast cancer $(\mathrm{n}=60)$ & Benign breast lesion $(\mathrm{n}=40)$ & $\chi^{2}$ \\
\hline High expression & 34 & 13 & 5.627 \\
Low expression & 26 & 27 & $0.018^{\mathrm{a}}$ \\
\hline
\end{tabular}

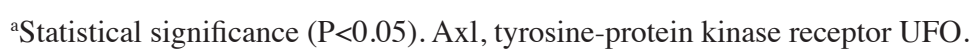

Table IV. Association between Axl expression and clinicopathological characteristics in breast cancer tissues.

\begin{tabular}{|c|c|c|c|c|}
\hline \multirow[b]{2}{*}{ Variables } & \multicolumn{2}{|c|}{ Axl expression } & \multirow[b]{2}{*}{$\chi^{2}$} & \multirow[b]{2}{*}{ P-value } \\
\hline & Low expression & High expression & & \\
\hline Age, years & & & 0.134 & 0.714 \\
\hline$\leq 50$ & 15 & 18 & & \\
\hline$>50$ & 11 & 16 & & \\
\hline Histological grade & & & 4.533 & $0.033^{\mathrm{a}}$ \\
\hline G1 & 9 & 4 & & \\
\hline $\mathrm{G} 2 / \mathrm{G} 3$ & 17 & 30 & & \\
\hline Tumor size, $\mathrm{cm}$ & & & 1.629 & 0.202 \\
\hline$<2$ & 8 & 16 & & \\
\hline$\geq 2$ & 18 & 18 & & \\
\hline Lymph node status & & & 0.008 & 0.930 \\
\hline N0 & 15 & 20 & & \\
\hline $\mathrm{N}+$ & 11 & 14 & & \\
\hline TNM stage & & & 2.267 & 0.322 \\
\hline I & 7 & 12 & & \\
\hline II & 11 & 17 & & \\
\hline III & 8 & 5 & & \\
\hline ER & & & 4.848 & $0.028^{\mathrm{a}}$ \\
\hline Negative & 15 & 10 & & \\
\hline Positive & 11 & 24 & & \\
\hline PR & & & 7.186 & $0.007^{\mathrm{a}}$ \\
\hline Negative & 19 & 13 & & \\
\hline Positive & 7 & 21 & & \\
\hline HER-2 & & & 0.979 & 0.322 \\
\hline Negative & 16 & 25 & & \\
\hline Positive & 10 & 9 & & \\
\hline $\mathrm{Ki}-67, \%$ & & & 3.279 & 0.070 \\
\hline$\leq 14$ & 5 & 14 & & \\
\hline$>14$ & 21 & 20 & & \\
\hline Molecular subtype & & & 5.984 & $0.014^{\mathrm{a}}$ \\
\hline Luminal type & 11 & 25 & & \\
\hline Non-luminal type & 15 & 9 & & \\
\hline
\end{tabular}

${ }^{\text {aS }}$ Statistical significance $(\mathrm{P}<0.05)$. Axl, tyrosine-protein kinase receptor UFO; ER, estrogen receptor; PR, progesterone receptor; HER2, human epidermal growth factor receptor 2; Ki-67, antigen Ki-67.

recurrence/metastasis and 10 cases (one patient died in an accident) of mortality were observed in the follow-up. Kaplan-Meier survival analysis (Fig. 2) demonstrated that there were no significant differences between Axl expression level and DFS/OS $\left(\mathrm{P}_{\text {log-rank }}>0.05\right)$. Therefore, it remains unclear whether there is an association between 

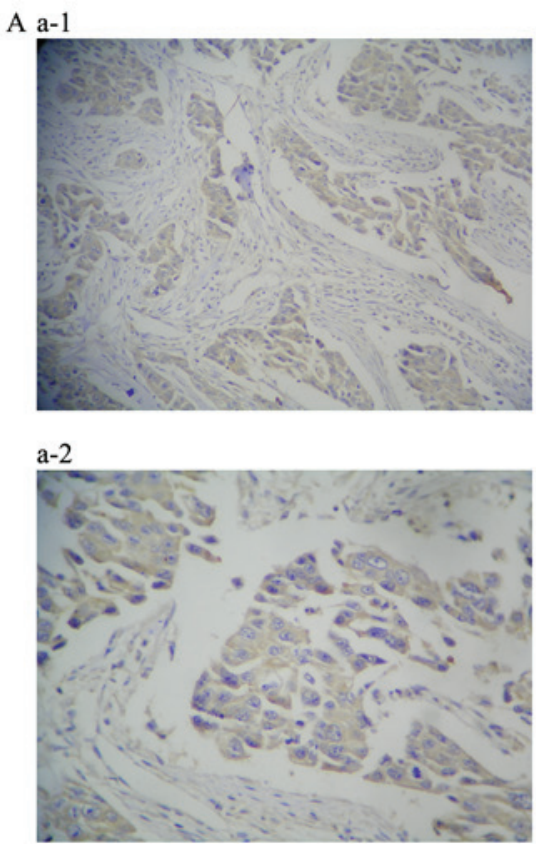

B b-1

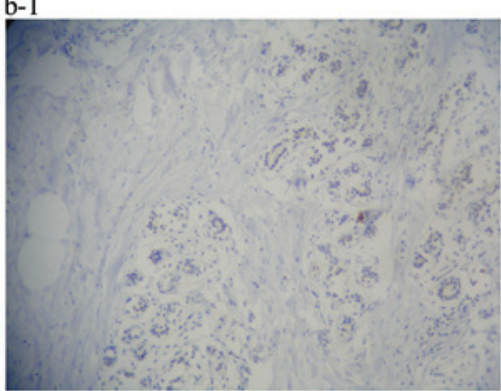

b-2

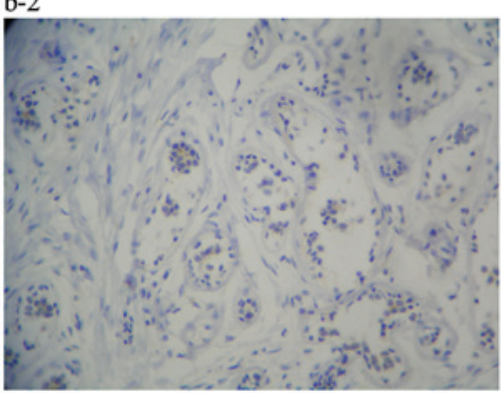

$\mathrm{C} \mathrm{c}-1$

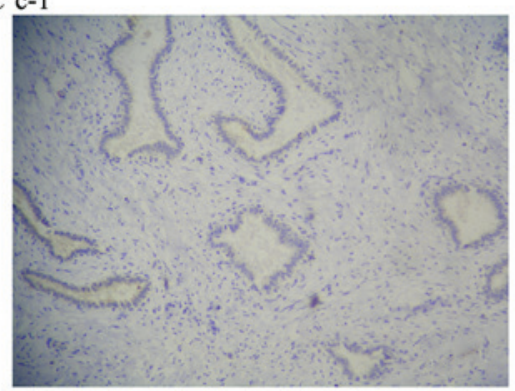

c-2

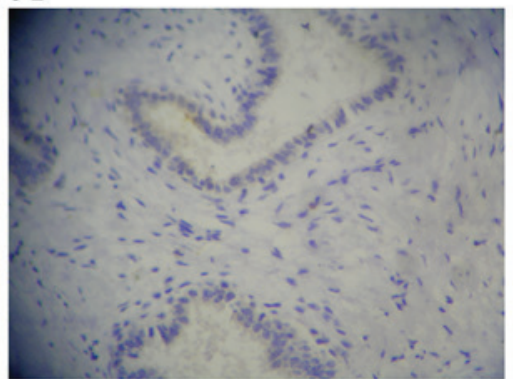

Figure 1. Immunohistochemical staining of Axl in breast cancer tissues and benign breast cancer tissues. (A) High expression of Axl in breast infiltrating ductal carcinoma: Axl expression was mainly detected in the cytoplasm and cell membrane; the positive cells were stained brown and diffusely distributed. (a-1, magnification, x200; a-2, magnification, x400). (B and C) Low expression of Axl in benign breast lesions: (B) Ax1 expression in mammary dysplasia (b-1, magnification, x200; b-2, magnification, x400); (C) Axl expression in breast fibroadenoma (c-1, magnification, x200; c-2, magnification, x400). Axl, tyrosine-protein kinase receptor UFO.
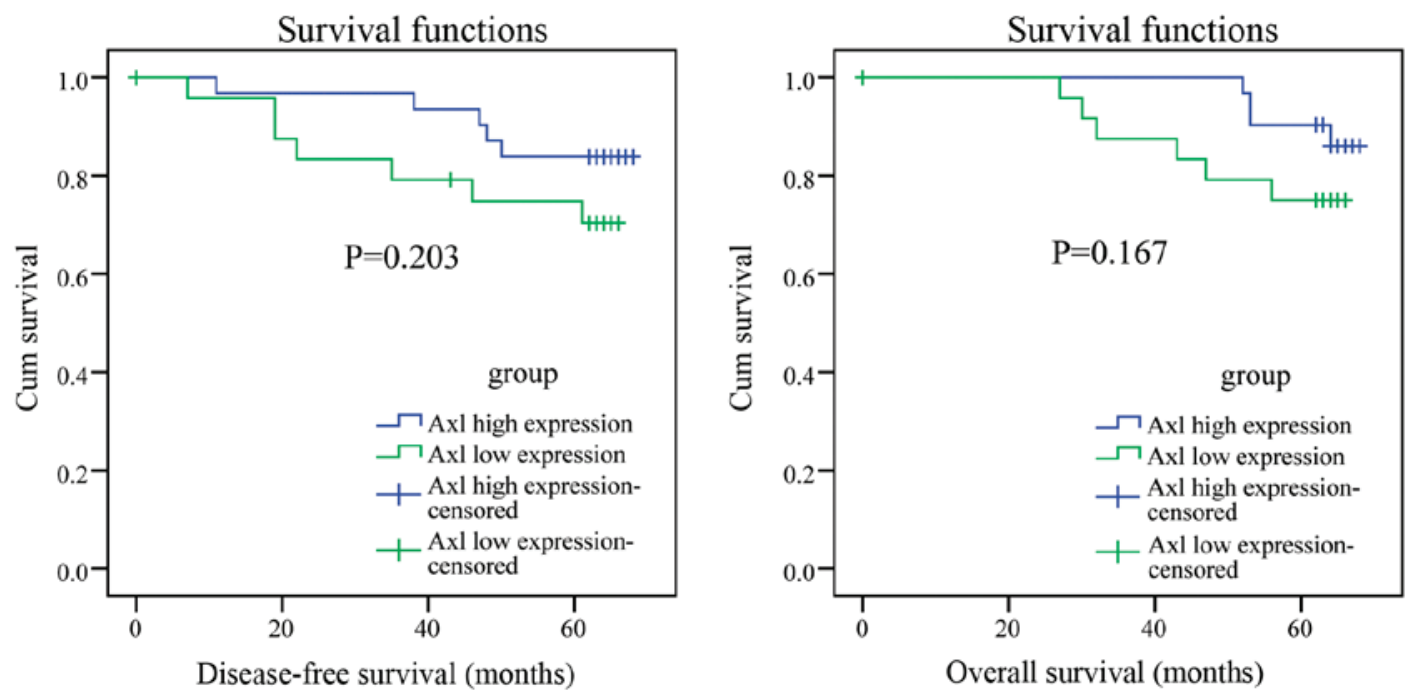

Figure 2. DFS and OS curves of breast cancer patients grouped according to the expression of Axl. (Kaplan-Meier curves). DFS, disease-free survival; OS, overall survival; Axl, tyrosine-protein kinase receptor UFO.

Axl expression and the OS/DFS of the breast cancer patients.

Cox regression analysis results for the prognostic factors of the 60 patients with breast cancer. Potential prognostic factors of 60 cases breast cancer patients were analyzed by the Cox proportional hazard model to explore the relationship between patient survival and several explanatory factors. The results demonstrated that HER-2 was the main factor associated with the DFS of patients with breast cancer $(\mathrm{P}=0.013$; Table VI). Age and HER-2 were the factors associated with the OS of breast cancer patients $(\mathrm{P}=0.037, \mathrm{P}=0.017$; Table VI). However there was no significant association between increased Axl expression and DFS/OS.

\section{Discussion}

The enhanced expression of Axl has been reported in different types of cancer, indicating that Axl may be important in the onset and progression of malignant tumors. Axl is a member of the TAM receptor tyrosine kinase subfamily, which regulates a series of pathophysiological processes including 
Table V. Spearman rank correlation of Axl expression with clinicopathological characteristics.

\begin{tabular}{|c|c|c|c|c|}
\hline \multirow[b]{2}{*}{ Factors } & \multicolumn{2}{|c|}{ Axl } & \multirow[b]{2}{*}{$\mathrm{r}$} & \multirow[b]{2}{*}{ P-value } \\
\hline & Low expression & High expression & & \\
\hline \multicolumn{5}{|c|}{ Histological grade } \\
\hline G1 & 9 & 4 & 0.275 & $0.034^{\mathrm{a}}$ \\
\hline G2/G3 & 17 & 30 & & \\
\hline \multicolumn{5}{|l|}{ ER status } \\
\hline Negative & 15 & 10 & 0.284 & $0.028^{\mathrm{a}}$ \\
\hline Positive & 11 & 24 & & \\
\hline \multicolumn{5}{|l|}{ PR status } \\
\hline Negative & 19 & 13 & 0.346 & $0.007^{\mathrm{a}}$ \\
\hline Positive & 7 & 21 & & \\
\hline
\end{tabular}

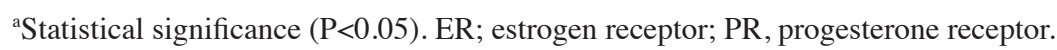

Table VI. Cox regression multi-factor analysis results for DFS and OS.

\begin{tabular}{lccccccc}
\hline Factors & B & SE & Wald & df & P-value & OR & $95 \%$ CI \\
\hline DFS & & & & & & & \\
HER-2 & 1.525 & 0.613 & 6.184 & 1 & $0.013^{\mathrm{a}}$ & 4.597 & $1.381-15.296$ \\
OS & & & & & & & \\
Age & 1.504 & 0.721 & 4.352 & 1 & $0.037^{\mathrm{a}}$ & 4.502 & $1.095-18.503$ \\
HER-2 & 1.591 & 0.668 & 5.670 & 1 & $0.017^{\mathrm{a}}$ & 4.907 & $1.325-18.175$ \\
\hline
\end{tabular}

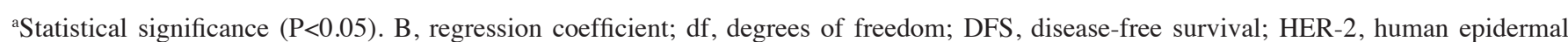
growth factor receptor 2; OS, overall survival; OR, odds ratio; CI, confidence interval; SE, standard error.

cell proliferation, migration, invasion, cytokine release and apoptosis (22-24). Furthermore, Holland et al (25) have demonstrated that Axl is essential for endothelial cell proliferation, migration, lumen formation, and angiogenesis regulation in tumor formation, which supports tumor progression.

In the present study, Axl expression was assessed by analysing samples taken from patients with breast cancer. The results indicated that Axl expression was significantly upregulated in breast cancer cells compared with benign breast lesions (mammary dysplasia and breast fibroadenoma), which is consistent with the results from a previous study by Berclaz et al (26). Therefore, increased Axl expression may facilitate tumorigenesis and the progression of breast cancer. Furthermore, it may be developed as a method of distinguishing between malignant and benign breast lesions.

The current study demonstrates that Axl overexpression correlates with histological grade in breast cancer. Ahmed et al (27) previously suggested that increased Axl expression was associated with the malignant grade of breast cancer. However, the current study did not find any association between Axl overexpression and other invasive indicators, such as tumor size, lymph node metastasis, TNM staging, HER-2, and Ki-67.

The results of previous studies are conflicting regarding the association between Axl expression and ER status in breast cancer. D'Alfonso et al (28) investigated 569 cases of breast cancer and suggested that there was no relationship between Axl expression and ER status. Ahmed et al (27) reported that high expression of Axl was associated with ER negativity, whereas, Berclaz et al (26) suggested that Axl expression was significantly associated with ER status; Axl expression was confined to ER positive tumors, however, not all ER positive tumors expressed the Axl protein. It was therefore hypothesized that ER mediates the upregulation and activation of Axl, and inhibits cell apoptosis by overexpressing Bcl-2 (an anti-apoptotic gene), leading to the malignant characteristics observed in tumor cells (26).

The results of the current study were similar to those obtained by Berclaz et al (26), however, a minority of ER negative tumors were also identified as overexpressing Axl. The link between Axl expression and ER status remains contentious, and further research investigating larger samples are warranted.

The current study demonstrated that Axl expression is positively correlated with PR status. This differs from the results of previous studies $(26,27)$, and suggests that there is a relationship between Axl expression and PR status. However, the mechanism behind this relationship remains unclear. Furthermore, it was demonstrated that Axl expression was higher in cases of luminal breast cancer than non-luminal 
cases, contrary to previous reports by Ahmed et al (27) and Neve et al (29). This may be due to the association between luminal subtype and ER status in breast cancer.

Patient follow-up demonstrated that there was no correlation between Axl expression and the prognosis of breast cancer, contrary to previous reports (26). This suggests that Axl expression is not associated with the clinical outcome of luminal and non-luminal type breast cancer. However, a correlation between Axl expression and breast cancer prognosis may indeed exist. The follow-up time in the present study was short, as the 5-year survival rate of patients with breast cancer is relatively high [currently $90.6 \%$ for those diagnosed in 2006 (30)]. A larger sample size with a longer follow-up time is required to make more concrete conclusions. Non-luminal (triple-negative and Basal) breast cancer is clinically more aggressive, with higher rates of recurrence and worse prognostic outcomes, compared with other types of breast cancer (31-33). The current study demonstrated that Axl expression was higher in luminal type breast cancer and positively correlated with histological grade. Luminal breast cancer often presents a better prognostic outcome, however the cancer histological grade positively correlates with tumor malignancy. Therefore, further study is required to determine whether there is a significant association between expression of Axl and the prognosis of patients with luminal type breast cancer.

In conclusion, the present study demonstrated that $\mathrm{Axl}$ is highly expressed in breast cancer tissues and is associated with poorly differential tumors, indicating that it serves an important role in the carcinogenesis and development of breast cancer. High Axl expression was significantly correlated with ER and PR status, indicating that Axl may contribute to the upregulation of ER and PR. However, its exact mechanism of action warrants further investigation. No obvious connection was demonstrated between levels of Axl expression and the prognosis of patients with breast cancer. Whether Axl expression is correlated with the prognosis of luminal type breast cancer patients requires further investigation. In the future, if a significant correlation is proven; Axl may be a promising biomarker for breast cancer malignancy and prognosis.

\section{References}

1. Al-Muhtaseb S: Serum and saliva protein levels in females with breast cancer. Oncol Lett 8: 2752-2756, 2014.

2. Siegel RL, Miller KD and Jemal A: Cancer statistics, 2016. CA Cancer J Clin 66: 7-30, 2016.

3. Chen W, Zheng R, Zhang S, Zhao P, Zeng H and Zou X: Report of cancer incidence and mortality in China, 2010. Ann Trans Med 2: 61, 2014.

4. O'Bryan JP, Frye RA, Cogswell PC, Neubauer AA, Kitch B, Prokop C, Espinosa R III, Le Beau M, Earp HT and Liu ET: axl, a transforming gene isolated from primary human myeloid leukemia cells, encodes a novel receptor tyrosine kinase. Mol Cell Biol 11: 5016-5031, 1991.

5. Korshunov V: Axl-dependent signalling: A clinical update. Clin Sci (Lond) 122: 361-368, 2012.

6. Li Y, Jia L, Ren D, Liu C, Gong Y, Wang N, Zhang X and Zhao Y: Axl mediates tumor invasion and chemosensitivity through PI3K/Akt signaling pathway and is transcriptionally regulated by slug in breast carcinoma. IUBMB Life 66 : 507-518, 2014

7. Yanagita M, Arai H, Nakano T, Ohashi K, Mizuno K, Fukatsu A, Doi T and Kita T: Gas6 induces mesangial cell proliferation via latent transcription factor STAT3. J Biol Chem 276: 42364-42369, 2001
8. Tai K, Shieh Y, Lee C, Shiah S and Wu C: Axl promotes cell invasion by inducing MMP-9 activity through activation of NF-kappaB and Brg-1. Oncogene 27: 4044-4055, 2008

9. Lim J and Thiery J: Epithelial-mesenchymal transitions: Insights from development. Development 139: 3471-3486, 2012.

10. Wu CW, Li AF, Chi CW, Lai CH, Huang CL, Lo SS, Lui WY and Lin WC: Clinical significance of AXL kinase family in gastric cancer. Anticancer Res 22: 1071-1078, 2002.

11. Ishikawa M, Sonobe M, Nakayama E, Kobayashi M, Kikuchi R, Kitamura J, Imamura N and Date H: Higher expression of receptor tyrosine kinase Axl, and differential expression of its ligand, Gas6, predict poor survival in lung adenocarcinoma patients. Ann Surg Oncol 20 (Suppl 3): S467-S476, 2013.

12. Sayan A, Stanford R, Vickery R, Grigorenko E, Diesch J, Kulbicki K, Edwards R, Pal R, Greaves P, Jariel-Encontre I, et al: Fra-1 controls motility of bladder cancer cells via transcriptional upregulation of the receptor tyrosine kinase AXL. Oncogene 31: 1493-1503, 2012

13. Avilla E, Guarino V, Visciano C, Liotti F, Svelto M, Krishnamoorthy G, Franco R and Melillo R: Activation of TYRO3/AXL tyrosine kinase receptors in thyroid cancer. Cancer Res 71: 1792-1804, 2011.

14. Koorstra JB, Karikari CA, Feldmann G, Bisht S, Rojas PL, Offerhaus GJ, Alvarez H and Maitra A: The Axl receptor tyrosine kinase confers an adverse prognostic influence in pancreatic cancer and represents a new therapeutic target. Cancer Biol Ther 8: 618-626, 2009.

15. Craven RJ, Xu LH, Weiner TM, Fridell YW, Dent GA, Srivastava S, Varnum B, Liu ET and Cance WG: Receptor tyrosine kinases expressed in metastatic colon cancer. Int $\mathrm{J}$ Cancer 60: 791-797, 1995.

16. Wu W, Bi C, Credille KM, Manro JR, Peek VL, Donoho GP, Yan L, Wijsman JA, Yan SB and Walgren RA: Inhibition of tumor growth and metastasis in non-small cell lung cancer by LY2801653, an inhibitor of several oncokinases, including MET. Clin Cancer Res 19: 5699-5710, 2013.

17. Mahadevan D, Cooke L, Riley C, Swart R, Simons B, Della Croce K, Wisner L, Iorio M, Shakalya K, Garewal H, et al: A novel tyrosine kinase switch is a mechanism of imatinib resistance in gastrointestinal stromal tumors. Oncogene 26: 3909-3919, 2007

18. Martinelli E, Martini G, Cardone C, Troiani T, Liguori G, Vitagliano D, Napolitano S, Morgillo F, Rinaldi B, Melillo R, et al: AXL is an oncotarget in human colorectal cancer. Oncotarget 6: 23281-23296, 2015.

19. Edge SB, Byrd DR, Compton CC, Fritz AG, Greene FL and Trotti A: AJCC cancer staging manual, vol. 649: Springer New York, 2010

20. Goldhirsch A, Winer EP, Coates AS, Gelber RD, Piccart-Gebhart M, Thurlimann B and Senn HJ; Panel members: Personalizing the treatment of women with early breast cancer: Highlights of the St Gallen International Expert Consensus on the Primary Therapy of Early Breast Cancer 2013. Ann Oncol 24: 2206-2223, 2013

21. Carlson RW, Moench SJ, Hammond ME, Perez EA, Burstein HJ, Allred DC, Vogel CL, Goldstein LJ, Somlo G, Gradishar WJ, et al: HER 2 testing in breast cancer: NCCN Task Force report and recommendations. J Natl Compr Canc Netw 4 (Suppl 3): S1-S22; quiz S23-S24, 2006.

22. Shiozawa Y, Pedersen EA, Patel LR, Ziegler AM, Havens AM, Jung Y, Wang J, Zalucha S, Loberg RD, Pienta KJ and Taichman RS: GAS6/AXL axis regulates prostate cancer invasion, proliferation and survival in the bone marrow niche. Neoplasia 12: 116-127, 2010.

23. Song X, Wang H, Logsdon CD, Rashid A, Fleming JB, Abbruzzese JL, Gomez HF, Evans DB and Wang H: Overexpression of receptor tyrosine kinase Axl promotes tumor cell invasion and survival in pancreatic ductal adenocarcinoma. Cancer 117: 734-743, 2011.

24. Bellosta P, Zhang Q, Goff S and Basilico C: Signaling through the ARK tyrosine kinase receptor protects from apoptosis in the absence of growth stimulation. Oncogene 15: 2387-2397, 1997.

25. Holland SJ, Powell MJ, Franci C, Chan EW, Friera AM, Atchison RE, McLaughlin J, Swift SE, Pali ES, Yam G, et al: Multiple roles for the receptor tyrosine kinase axl in tumor formation. Cancer Res 65: 9294-9303, 2005.

26. Berclaz G, Altermatt HJ, Rohrbach V, Kieffer I, Dreher E and Andres AC: Estrogen dependent expression of the receptor tyrosine kinase axl in normal and malignant human breast. Ann Oncol 12: 819-824, 2001. 
27. Ahmed L, Nalwoga H, Arnes J, Wabinga H, Micklem D and Akslen L: Increased tumor cell expression of Axl is a marker of aggressive features in breast cancer among African women. APMIS 123: 688-696, 2015.

28. D'Alfonso TM, Hannah J, Chen Z, Liu Y, Zhou P and Shin SJ: Axl receptor tyrosine kinase expression in breast cancer. J Clin Pathol 67: 690-696, 2014.

29. Neve R, Chin K, Fridlyand J, Yeh J, Baehner F, Fevr T, Clark L, Bayani N, Coppe J, Tong F, et al: A collection of breast cancer cell lines for the study of functionally distinct cancer subtypes. Cancer Cell 10: 515-527, 2006.

30. Chen L, Linden H, Anderson B and Li C: Trends in 5-year survival rates among breast cancer patients by hormone receptor status and stage. Breast Cancer Res Treat 147: 609-616, 2014.
31. Haffty B, Yang Q, Reiss M, Kearney T, Higgins S, Weidhaas J, Harris L, Hait W and Toppmeyer D: Locoregional relapse and distant metastasis in conservatively managed triple negative early-stage breast cancer. J Clin Oncol 24: 5652-5657, 2006

32. Dent R, Trudeau M, Pritchard KL, Hanna WM, Kahn HK, Sawka CA, Lickley LA, Rawlinson E, Sun P and Narod SA: Triple-negative breast cancer: Clinical features and patterns of recurrence. Clin Cancer Res 13: 4429-4434, 2007.

33. Rakha E, El-Sayed M, Green A, Lee A, Robertson J and Ellis I: Prognostic markers in triple-negative breast cancer. Cancer 109: 25-32, 2007. 